\title{
High Blood Platelet Count in Lactants as an Early Sign of Avitaminosis B.
}

\author{
59th* Report of the Peroxidase Reaction.
}

\author{
By \\ Jun Kimura. \\ (木 村 順) \\ (From the Department of Pediatrics, Faculty of Medi- \\ cine, Tohoku Imperial University, Sendai. \\ Director: Prof. A. Sato.)
}

In a preceding paper ${ }^{1)}$ I have shown that most of "healthy" mothers secreting human milk negative to Arakawa's reaction, ${ }^{2)}$ are in a state of avitaminosis $\mathrm{B}$ on the basis of the results of blood platelet count. Here a summary result is cited from the paper (Cf. Table I).

As was shown in this table (Table I), almost all the cases of strongly A rakawa-positive cases are of the platelet count from 100 to 400 thousands, and the majority of all the A rak awa-negative cases are of the count from 400 to 1,000 thousands.

\section{TABLE I.}

Distribution of A rakawa-positive and -negative cases according to blood platelet count.

\begin{tabular}{c|c|c}
\hline $\begin{array}{c}\text { Number of blood } \\
\text { platelet }\end{array}$ & $\begin{array}{c}\text { With strongly A rakawa- } \\
\text { positive cases } \\
(52 \text { in all })\end{array}$ & $\begin{array}{c}\text { With completely Arakawa- } \\
\text { positive cases } \\
(48 \text { in all) }\end{array}$ \\
\hline $100,000-400,000$ & $96.2 \%$ (50 cases) & $18.8 \%$ ( 9 cases) \\
$410,000-700,000$ & $3.8 \%\left(\begin{array}{c}2 \text { cases }) \\
710,000-1000,000\end{array}\right.$ & $\begin{array}{c}60.4 \% \text { (29 eases) } \\
20.8 \% \text { (10 cases) }\end{array}$
\end{tabular}

* This is my $2 n d$ report on the relation between avitaminosis $B$ and blood platelet count.

1) J. Ki m u ra, Tohoku J. Exp. Med., 1934, 23, 494.

2) T. Arak a wa, Tohoku J. Exp. Med., 1930, 16, 118. 
A verage of blood platelet counts according to A rakawapositive and -negative cases.

\begin{tabular}{c|c|c}
\hline & $\begin{array}{c}\text { Strongly Arakaw a- } \\
\text { positive cases } \\
(52 \text { in all })\end{array}$ & $\begin{array}{c}\text { Completely A rakawa- } \\
\text { negative cases } \\
(48 \text { in all) }\end{array}$ \\
\hline $\begin{array}{c}\text { Number of blood } \\
\text { platelets }\end{array}$ & 266,000 & 560,000
\end{tabular}

* Table V (A) (B) in the preceding paper. 23).

Errata in the 47 th Report of the Peroxidase Reaction (Tohoku J. Exp. Med., 1934

1) Table $\mathrm{V}$ (B) should be as follows:

Average of blood platelet counts according to A rakawapositive and -negative cases.

\begin{tabular}{c|c|c}
\hline & $\begin{array}{c}\text { Strongly Arakawa- } \\
\text { positive cases } \\
\text { (52 in all) }\end{array}$ & $\begin{array}{c}\text { Completely Arakawa- } \\
\text { negative cases } \\
(48 \text { in all) }\end{array}$ \\
\hline $\begin{array}{c}\text { Number of blood } \\
\text { platelets }\end{array}$ & 266,000 instead of 256,000 & 560,000 instead of $\mathbf{5 7 5 , 0 0 0}$
\end{tabular}

2) In the 10th and 11 th line respectively of P. 503:-

266,000 instead of 256,000

560,000 instead of 575,000

All the results shown in the preceding paper') of mine concerned only strongly A rak a wa-positive and completely A raka wa-negative cases, or, only those mothers whose milk was normally or strongly positive** to Arakawa's reaction or those lactants whose milk was completely negative.*** As to the intermediate case, i. c. the cases with human milk of different intermediate intensities of Arakawa's reaction it may not be difficult to suppose that they will come between both extremities. The present paper treats of the actual result of investigation.

\section{Method of Investigation.}

1. Materials. As stated above, mothers with humen milk of A rakawa's reaction of different intensities were examined, though strongly A rak a wa-positive and completely A r a k a w a-negative cases were also examined.

All' the lactants were "healthy" and of course they had not been

* A rakawa's reaction of the intensity $(H+$ or $+t)$ in one minute.

*** Arakawa's reaction of the intensity $(-)$ in five minutes. 
taking vitamine B preparations. However, I excluded mothers who had menses ${ }^{3 j}$ at the time.

2. Platelet count. I used Lampert's $\mathrm{s}^{4)}$ method. The ear lobe was cleaned with ether, and a cut was made with Frank's needle. Blood was takan into the "A-thrombit" and diluted with Tyrode's solution. After shaking the pipette for a few minutes, the sixth drop of the contents was examined for blood platelets. Blood taking took place between 10 and 11 A.M., when mothers were in a fasting state.

\section{Results of Investigation.}

100 cases were examined during 4 months beginning August 1933. All the results will be shown in Tables II, III and IV.

1. Distribution of A rakawa-positive and-negative and intermediate cases according to the platelet count. Strongly A rakawapositive cases were not so numerous as in the preceding paper, ${ }^{12}$ but the majority of all the cases examined were of the count from $100-$ 300 thousands, while a large majority of completely A raka wa-negative cases were of the count from 400-1,000 thousands. The above result is almost as described in the preceding paper. ${ }^{1)}$

Now if one gives a glance at Table $V$, one will see that all the cases of intermediate reactions have fallen between the strongly (or normally) A rak a wa-positive and the completely A raka wa-negative cases (Cf. Table V). And the result will further be shown more simply in Table VI (A) and in Figure, because all the strongly Arakawapositive cases have come under the column 100-400,000, and the large majority of completely A rakaw a-negative cases under the columns 410,000-700,000 and 710,000-1,000,000, while cases with intermediate reactions are partly (almost half the cases) under the column 100,000400,000 and partly (slightly more than half the cases) under the column 410,000-700,000 (Cf. Table VI A).

If the average figures of the strongly A rak a wa-positive, intermediate, and completely A rakaw a-negative cases are given in Table VI B, then the cases with strong (or normal) A rakawa's reaction have shown an average of 267,000 , the intermediate cases an average of 428,000 , and the completely Arak a wa-negative cases an average of 586,000. The relation among the three is thus $10: 16: 22$, or if rounded off, $1: \frac{3}{2}: 2$ (Cf. Tables V. VI, VII and Figure).

3) T. O otsuk a, Kyotofuritsu Ikadaigaku Zasshi., 1932, 6, 2434.

4) H. L a m pert, Verh. Dtsch. Ges. inn. Med., 1931, 43, 92. 
High Platelet Count as Sign of Avitaminosis B

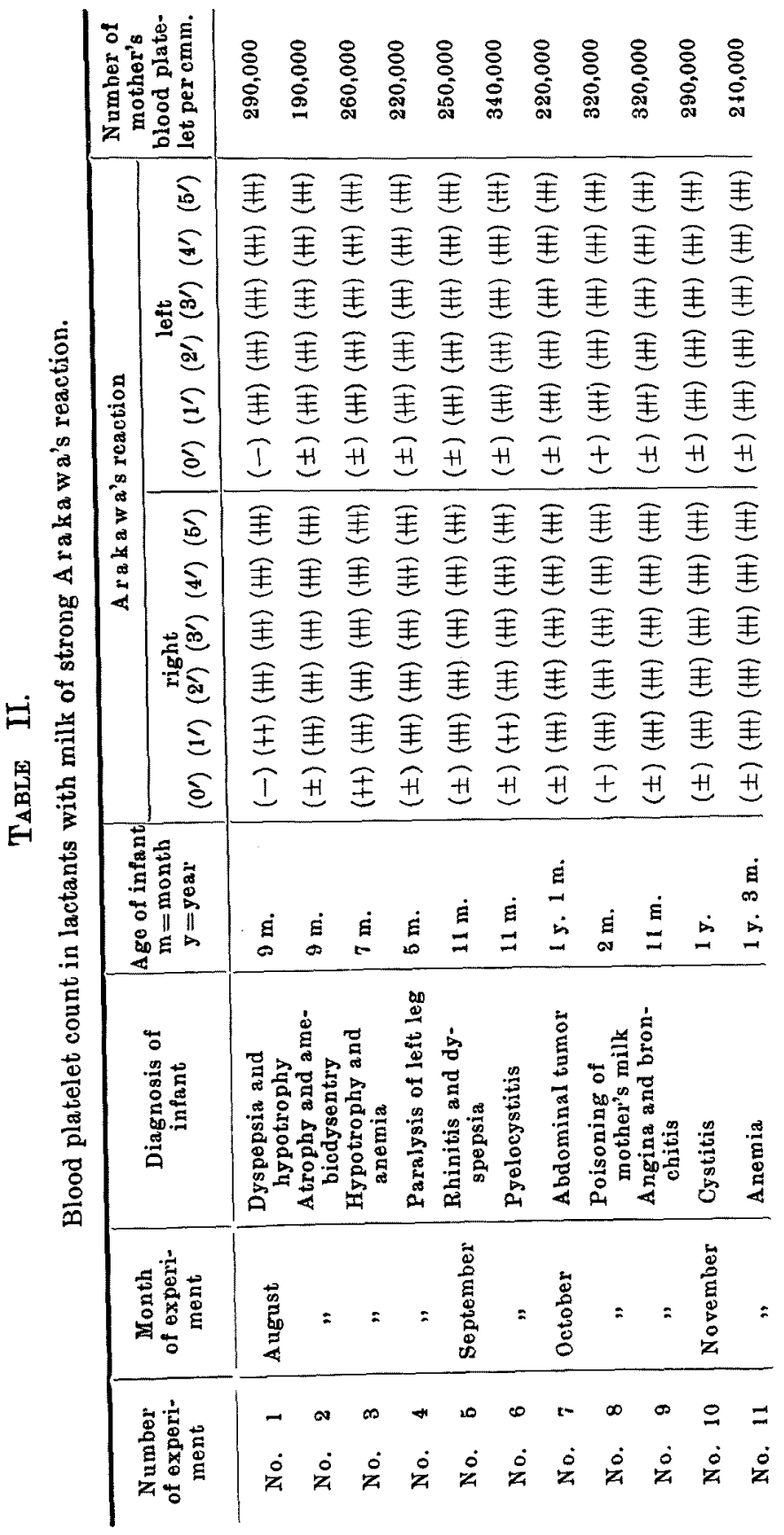




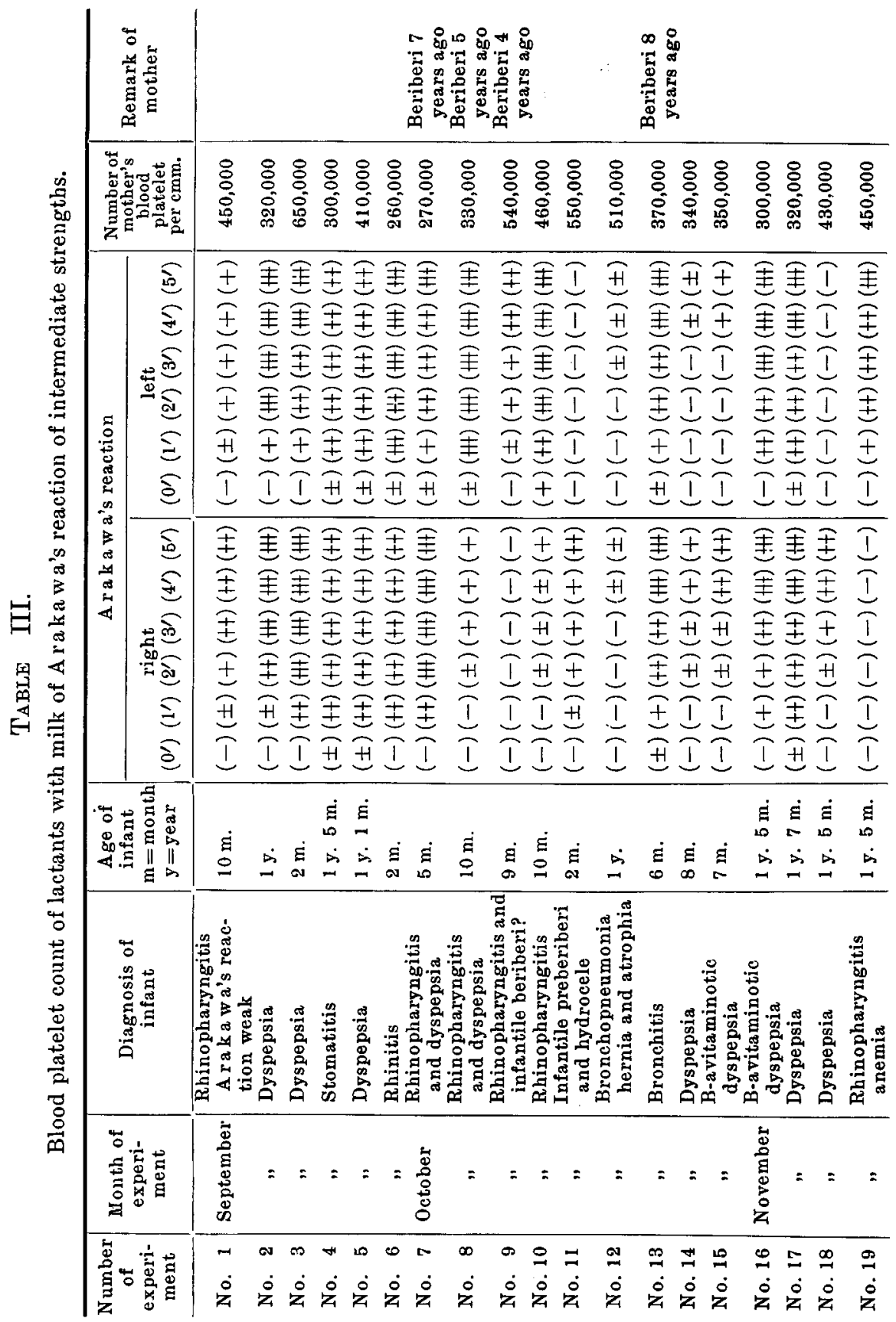




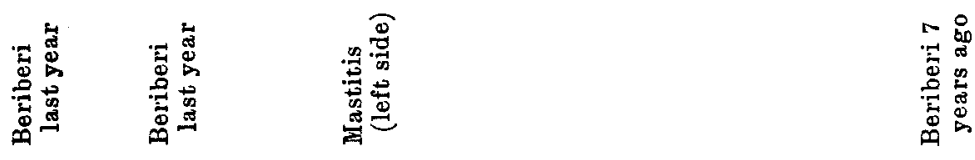

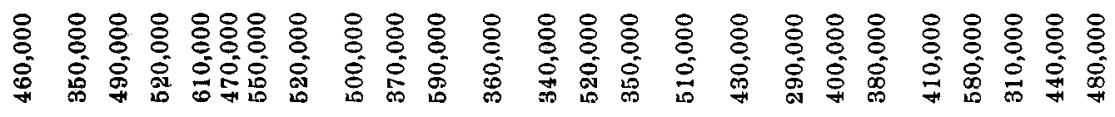

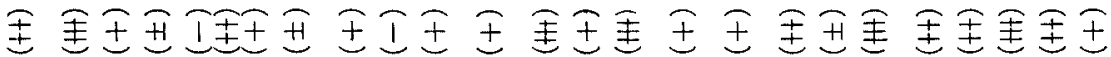

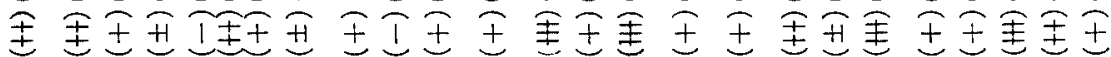

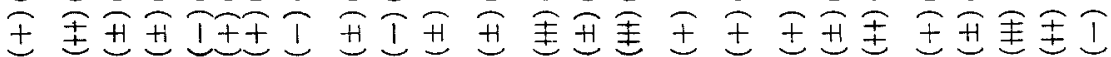

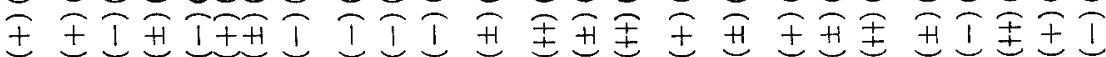

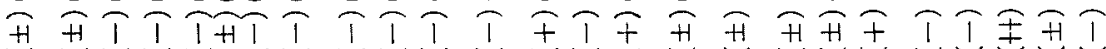
ITITTIITITITITITITTITITII

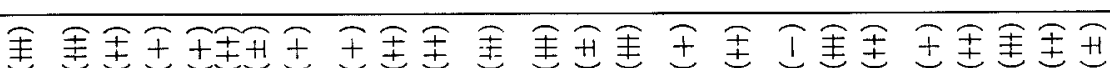

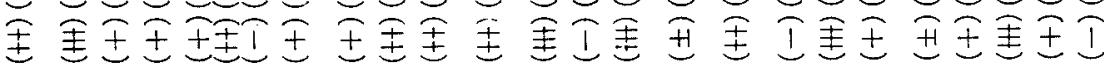

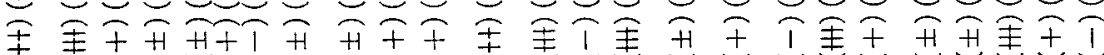

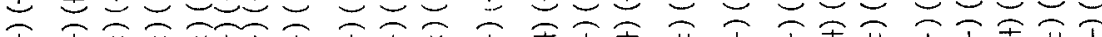

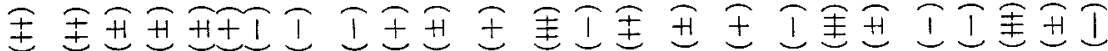

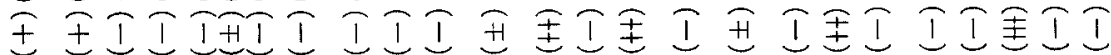
I IIIIIIIIIIIIIIIII开III开II

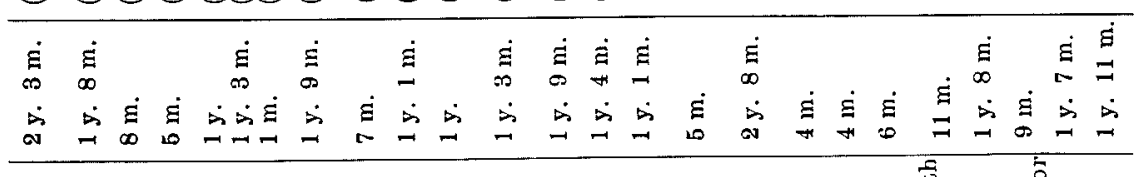

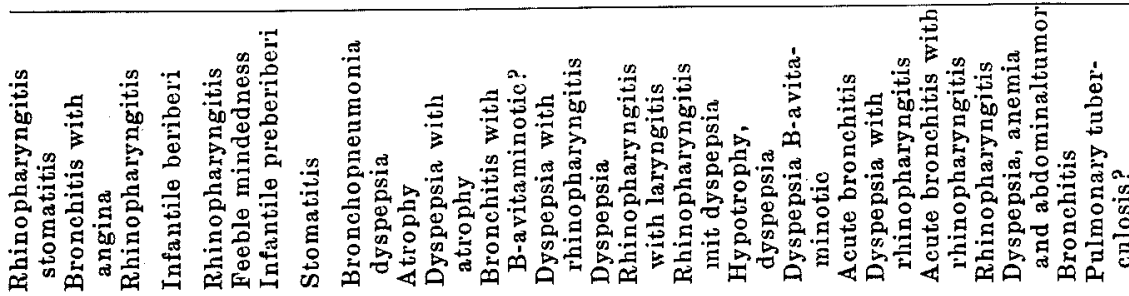

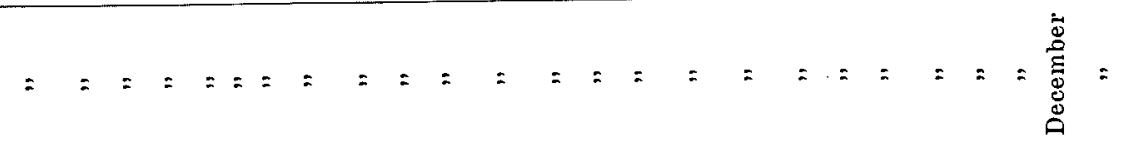

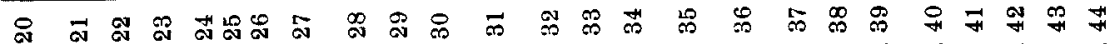

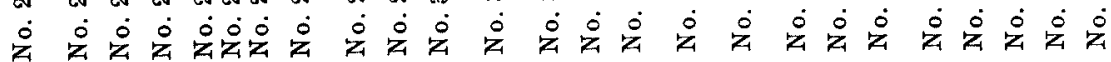




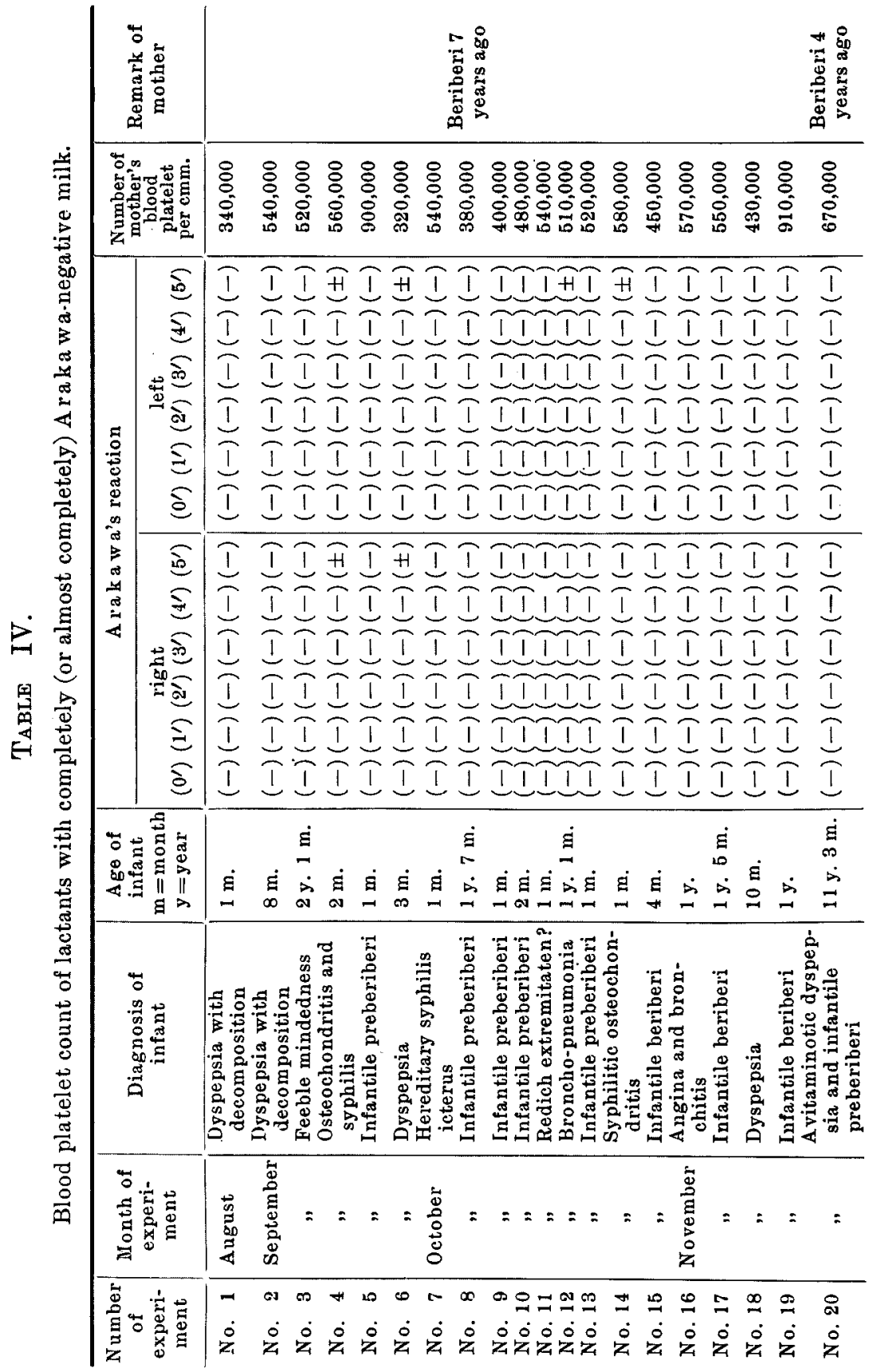



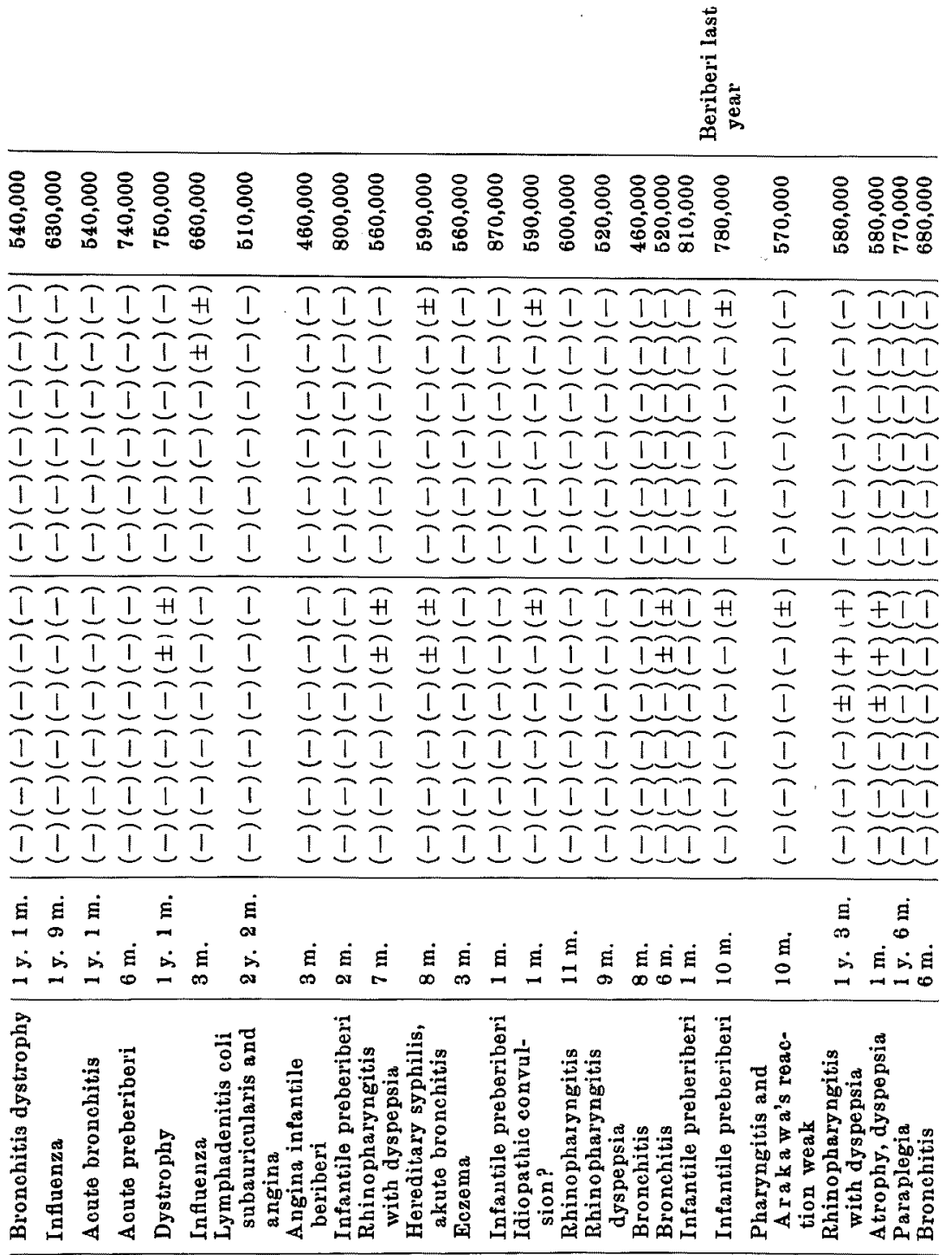

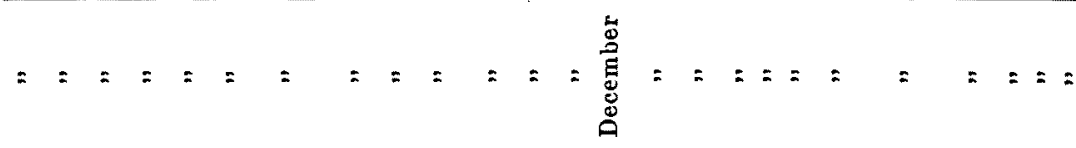

ส

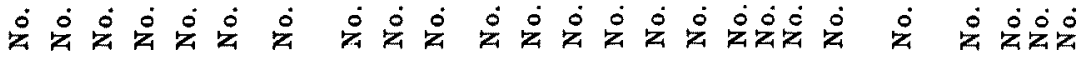




\section{TABLE $V$.}

Distribution of A rakawa-positive, -intermediate and -negative cases according to the blood platelet count.

\begin{tabular}{c|c|c|c}
\hline $\begin{array}{c}\text { Number of blood } \\
\text { platelet }\end{array}$ & $\begin{array}{c}\text { Strongly* } \\
\text { Arak a wa-positive } \\
\text { cases (11 in all) }\end{array}$ & $\begin{array}{c}\text { Cases with inter- } \\
\text { mediate A r a a wa's } \\
\text { reaction (44 in all) }\end{array}$ & $\begin{array}{c}\text { Completely (or } \\
\text { almost completely) } \\
\text { A ra a w a-negative } \\
\text { cases (45 in all) }\end{array}$ \\
\hline $100,000-200,000$ & $9.2 \%$ (1 case) & 0 & \\
$210,000-300,000$ & $63.6 \%$ (7 cases) & $11.4 \%$ (5 caess) & 0 \\
$310,000-400,000$ & $27.2 \%$ (3 cases) & $31.8 \%$ (14 cases) & $8.9 \%$ (4 cases) \\
$410,000-500,000$ & 0 & $29.5 \%$ (13 cases) & $11.1 \%$ cases) \\
$510,000-600,000$ & 0 & $22.7 \%$ (10 cases) & $\mathbf{5 1 . 1 \%}$ (23 caess) \\
$610,000-700,000$ & 0 & $4.5 \%$ (2 cases) & $8.9 \%$ (4 cases) \\
$710,000-800,000$ & 0 & 0 & $11.1 \%$ (5 cases) \\
$810,000-900,000$ & 0 & 0 & $6.7 \%$ (3 cases) \\
$910,000-1000,000$ & 0 & 0 & $2.2 \%$ (1 case)
\end{tabular}

* Strongly A ra ka wa-positive (and normally A ra k a wa-positive) cases (also in Tables I, VI, VII and IX).

\section{TABle VI (A).}

Distribution of A rakawa-positive, -intermediate and -negative cases according to the blood platelet count.

\begin{tabular}{|c|c|c|c|}
\hline $\begin{array}{c}\text { Number of blood } \\
\text { platelet }\end{array}$ & $\begin{array}{c}\text { Strongly } \\
\text { A raka w a-positive } \\
\text { cases (11 in all) }\end{array}$ & $\begin{array}{l}\text { Cases with inter- } \\
\text { mediate A a k a wa's } \\
\text { reaction ( } 44 \text { in all) }\end{array}$ & $\begin{array}{l}\text { Completely (or } \\
\text { almost completely) } \\
\text { Arakawa-negative } \\
\text { cases ( } 45 \text { in all) }\end{array}$ \\
\hline $\begin{array}{l}100,000-400,000 \\
410,000-700,000 \\
710,000-1000,000\end{array}$ & $\begin{array}{l}100 \% \text { (11 cases) } \\
0 \\
0\end{array}$ & $\begin{array}{l}43.2 \%(19 \text { cases }) \\
56.7 \%(25 \text { caess }) \\
0\end{array}$ & $\begin{array}{c}8.9 \% \text { ( } 4 \text { cases }) \\
71.1 \% \text { (32 cases) } \\
20.0 \% \text { (9 cases })\end{array}$ \\
\hline
\end{tabular}

\section{TABLE VI (B).}

Average according to A ra kaw a-positive -intermediate and -negative cases of blood platelet counts.

\begin{tabular}{c|c|c|c}
\hline & $\begin{array}{c}\text { Strongly } \\
\text { A rakawa-positive } \\
\text { cases (11 in all) }\end{array}$ & $\begin{array}{c}\text { Cases with inter- } \\
\text { mediate A a ka a's } \\
\text { reaction (44 in all) }\end{array}$ & $\begin{array}{c}\text { Completely (or } \\
\text { almost completely) } \\
\text { A ra k a wa-negative } \\
\text { cases (45 in all) }\end{array}$ \\
\hline $\begin{array}{c}\text { Number of blood } \\
\text { platelet }\end{array}$ & 267,000 & 428,000 & 586,000
\end{tabular}




\section{TABLE VII (A).}

Distribution of A rakawa-positive, -intermediate and -negative cases according to blood platelet count.

\begin{tabular}{c|c|c|c}
\hline $\begin{array}{c}\text { Number of blood } \\
\text { platelet }\end{array}$ & $\begin{array}{c}\text { Strongly } \\
\text { A ra k a a-positive } \\
\text { cases (63 in all) }\end{array}$ & $\begin{array}{c}\text { Cases with inter- } \\
\text { mediate A ra kawa's } \\
\text { reaction (44 in all) }\end{array}$ & $\begin{array}{c}\text { Completely (or } \\
\text { almost completely) } \\
\text { Ara a a a-negative } \\
\text { cases (93 in all) }\end{array}$ \\
\hline $100,000-200,000$ & $15.9 \%$ (10 cases) & 0 & \\
$210,000-300,000$ & $60.3 \%$ (38 cases) & $11.4 \%$ (5 cases) & $4.3 \%$ (4 cases) \\
$310,000-400,000$ & $20.6 \%$ (13 cases) & $31.8 \%$ (14 cases) & $9.7 \%$ (9 cases) \\
$410,000-500,000$ & $1.6 \%$ (1 case) & $29.5 \%$ (13 cases) & $18.3 \%$ (17 cases) \\
$510,000-600,000$ & $1.6 \%$ (1 case) & $29.9 \%$ (10 cases) & $35.5 \%$ (32 cases) \\
$610,000-700,000$ & 0 & $4.5 \%$ (2 cases) & $1.8 \%$ (11 cases) \\
$710,000-800,000$ & 0 & 0 & $8.6 \%$ (8 cases) \\
$810,000-900,000$ & 0 & 0 & $8.6 \%$ (8 cases) \\
$910,000-1000,000$ & 0 & 0 & $3.2 \%$ (3 cases)
\end{tabular}

\section{TABLE VII (B).}

Distribution of Arakawa-positive, -intermediate and -negative cases according to the blood platelet count.

\begin{tabular}{|c|c|c|c|}
\hline $\begin{array}{c}\text { Number of blood } \\
\text { platelet }\end{array}$ & $\begin{array}{c}\text { Strongly } \\
\text { A rakawa-positive } \\
\text { cases }(63 \text { in all })\end{array}$ & $\begin{array}{l}\text { Cases with inter- } \\
\text { mediate A r a k a wa- } \\
\text { reaction ( } 44 \text { in all) }\end{array}$ & $\begin{array}{l}\text { Completely (or } \\
\text { almost completely) } \\
\text { Araka wa-negative } \\
\text { cases (93 in all) }\end{array}$ \\
\hline $\begin{array}{l}100,000-400,000 \\
410,000-700,000 \\
710,000-1000,000\end{array}$ & $\begin{array}{l}96.8 \%(61 \text { cases }) \\
3.2 \% \text { ( } 2 \text { cases }) \\
0\end{array}$ & $\begin{array}{l}43.2 \% \text { (19 cases) } \\
56.7 \% \text { (25 cases) } \\
0\end{array}$ & $\begin{array}{l}14.0 \%(13 \text { cases } \\
65.6 \%(61 \text { cases }) \\
20.4 \%(19 \text { cases })\end{array}$ \\
\hline
\end{tabular}

\section{TABLE VII (C).}

Average according to A raka wa-positive -intermediate and -negative case of blood platelet counts.

\begin{tabular}{c|c|c|c}
\hline & $\begin{array}{c}\text { Strongly } \\
\text { Arakawa-positive } \\
\text { cases (63 in all) }\end{array}$ & $\begin{array}{c}\text { Cases with inter- } \\
\text { mediate Arak awa- } \\
\text { reaction (44 in all) }\end{array}$ & $\begin{array}{c}\text { Completely (or } \\
\text { almost completely) } \\
\text { A rak awa-negative } \\
\text { cases (93 in all) }\end{array}$ \\
\hline $\begin{array}{c}\text { Number of blood } \\
\text { platelet }\end{array}$ & 267,000 & 428,000 & 573,000
\end{tabular}


Fig. 1. Distribution of A rakawa-positive,-intermediate and -negative cases.

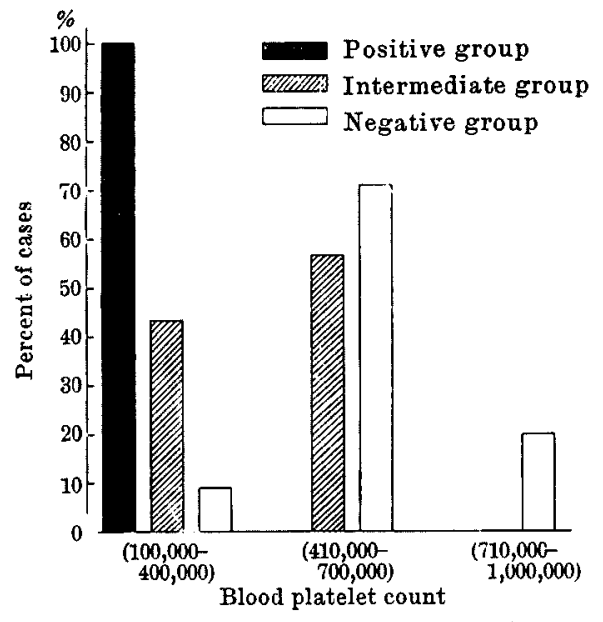

In the preceding paper, ${ }^{1)}$ it has been shown that "healthy" mothers with completely Arakawa-negative reaction are already in a state of avitaminosis B. Now how about those cases with Arakawa's reaction of intermediate strengths? I shall come to this problem in the next paragraph.

2. Distribution of platelet count of intermediate cases according to the strength of Arakawa's reaction. All the examined cases in this paper are divided into 7 groups according to the strength of Arakawa's reaction, and the average figure of the platelet count of each group is given. Then the result will be as in the following table (Cf. Table VIII).

The table (Table VIII) will show at a glance that even among the cases with intermediate reactions, the blood platelet count is different according to the intensity of A rakawa's reaction, though unfortunately the cases in each group are not uniform in number and the cases

\section{TABLE VIII.*}

Distribution of intermediate cases according to the strength of the reaction and the average platelet count of each group.

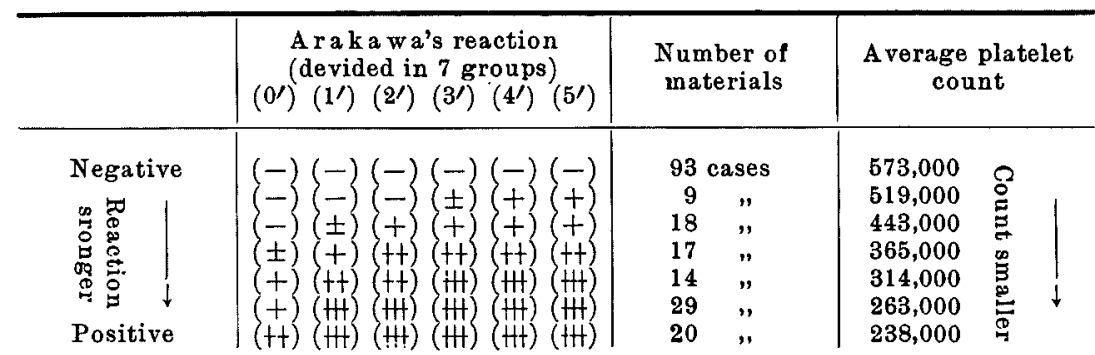

* This table is compiled of not only all the few cases with equal reaction on both breasts but also all the cases with different reaction; in the latter the A r a k a w reaction was expressed in the mean intensity. This is not necessarily unreasonable if the paper of $T$ ak a mats $\mathrm{u}$ (the 46th Report of the Peroxidase Reaction) is taken into consideration. 
with actually equal reactions on both breasts are only but few in number. But it is very interesting to see, as the arrows in the table show, that the average platelet count becomes smaller, as the Arakaw a reaction becomes stronger.

As stated above at the beginning of the present paper, it is not difficult to suppose that the cases with A rakawa's reaction of intermediate strengths will, with respect to blood platelet count, come half-way between the strongly A r a k a w a-positive and the completely Arakawa-negative cases. But such a result as shown in Table VIII was more than $I$ had expected. A general rule can be made on the basis of the result in this table: The weaker tho A rakawa reaction, the larger is the blood platelet count.

Now is a case with an intermediate reaction already in a state of avitaminosis B? If we consider the platelet count of 100-300 thousands as normal, then the group of A rak a wa's reaction* $(t)(t+)(+t)(+H)$ (WI) on both breasts - or the group with the average count $314,000-$ should be already in a state of B-avitaminose, or at least on the brink of B-avitaminosis. Or, some cases belonging to the group may be healthy and the others will already be B-avitaminotic.

It has again been made probable that only strongly or normally A rakawa-positive cases can generally be said to be free from avitaminosis $B$, while mothers with weaker reactions are generally in a state of avitaminosis $B$, in spite of their assurance that they are "healthy."

\section{Appendix.}

By way of appendix, I have arranged the infantile cases of all the materials examined in the preceding and present papers, according to the intensity of A rakawa's reaction and the kinds of diseases, and although I do not expect to draw a conclusion from this small table, it is interesting to note a rough distribution of infantile dyspepsia and infantile beriberi among others (Cf. Table IX).

\section{Remarks.}

It is a matter of course that a given case with A.R. $(-)(-)(-)( \pm)$

* Arakawa's reaction $(t)(t t)(t t)(H)(H+) \ldots$ Arakawa's reaction $(t)$ $1^{\prime}(t+) 2^{\prime}(t+) 3^{\prime}(H) 4^{\prime}\left(H+5^{\prime}\right.$. 
$(+) *$ may show a lower platelet count than another with A. R. $(-)(-)$ $( \pm)(+)(t+)$. Besides, the former case with A. R. $(-)(-)(-)( \pm)(+)$ may secrete human milk with A. R. $(-)(-)( \pm)(+)(+t)$ the next day: Ara$\mathrm{k}$ awa's reaction is not, in most cases, very strictly constant as will be seen from Prof. Sato and Moriwaki's paper,** read under the title : Proposal of Function Test of Mammary Glands, in April, 1934, in the General Meeting of the Japanese Pediatric Society, Tokyo, but, as has been shown by $\mathrm{Ug} \mathrm{a}^{5}$ (the 56th Report on the Peroxidase Reaction), reliably constant. The present work treats rather with groups with different reactions, not with individual cases. As to individual cases subject to more or less remarkable daily fluctuation of Arakawa's reaction, we shall be able to report in a future treatise.

\section{TABLE IX.}

Distribution of A rakawa-positive, -intermediate and -negative cases according to diagnosis of infants.

\begin{tabular}{l|c|c|c}
\hline $\begin{array}{c}\text { Diagnosis of } \\
\text { infant }\end{array}$ & $\begin{array}{c}\text { Strongly } \\
\text { Arakawa-positive } \\
\text { cases (63 in all) }\end{array}$ & $\begin{array}{c}\text { Cases with inter- } \\
\text { mediate A ra a a a } \\
\text { positive cases }\end{array}$ & $\begin{array}{c}\text { Completely (or } \\
\text { almost completely) } \\
\text { Ara a a a-negative } \\
\text { cases (93 in all) }\end{array}$ \\
\hline Dyspepsia & $30.1 \%$ (19 cases) & $38.8 \%$ (17 cases) & $30.1 \%$ (28 cases) \\
Infantile beriberi & 0 & $9.1 \%$ (4 cases) & $29.6 \%$ (21 cases) \\
Congenital syphilis & 0 & 0 & $16.2 \%$ (11 cases) \\
Bronchitis & $4.8 \%$ (3 cases) & $13.6 \%$ (6 cases) & $5.4 \%$ (4 cases) \\
Rhinopharyngitis & $14.3 \%$ (9 cases) & $20.5 \%$ (9 cases) & $3.2 \%$ (3 cases)
\end{tabular}

\section{Summary.}

In a preceding paper ${ }^{1)}$ of mine I have stated on the basis of blood platelet count that most of "healthy" mothers secreting milk completely negative to Arakawa's reaction are generally in a state of avitaminosis B. In the present paper cases with human milk with intermediate Arakawa's reaction have been investigated. And as was expected, those cases have shown intermediate figures of blood platelet count between those of the strongly Arakawa-positive and the completely Arakawa-negative cases.

The result may be shown better by a small table accompanying (Cf. Table X). $4^{\prime}(+) 5^{\prime}$.

* A. R. $(-)(-)(-)( \pm)(+)$... A rak aw a's reaction $(-) 1^{\prime}(-) 2^{\prime}(-) 3^{\prime}( \pm)$

** The original will be published in the near future in this journal.

5) Y. U ga, Tohoku J. Exp. Med., 1935, 25, 564. 
TABLE $X$

\begin{tabular}{|c|c|}
\hline Arakawa's reaction & Blood platelet count \\
\hline 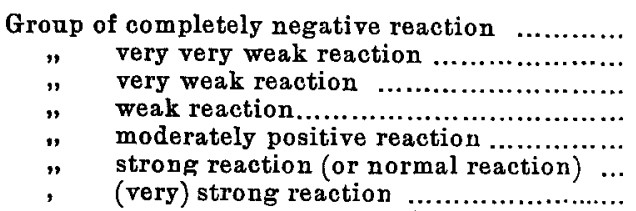 & $\begin{array}{l}\mathbf{5 7 0 , 0 0 0} \\
\mathbf{5 2 0 , 0 0 0} \\
440,000 \\
360,000 \\
310,000 \\
260,000 \\
\mathbf{2 4 0 , 0 0 0}\end{array}$ \\
\hline
\end{tabular}

It has been stated on the besis of blood platelet count that cases with these intermediate reactions are in a state of $\mathrm{B}$-avitaminosis and that even the cases with $(+)(+t)(+t)(+H)(H)(H+) *$ are probably on the brink of avitaminosis B.

\section{Conclusions.}

"Healthy" mothers who secrete milk completely negative to Arakawa's reaction are, as shown in my preceding paper, ${ }^{1)}$ in a state of B-avitaminosis. And "healthy" mothers with milk of Ara$\mathbf{k}$ a wa's reaction of intermediate strengths are, as shown on the basis of platelet count, either in a state of B-avitaminosis or on the brink of B-avitaminosis.

* Arakawa's reaction is positive in such a way as $(+) 0^{\prime}(t+) 1^{\prime},(+t) 2,(H+) 3^{\prime}$, (H) $4^{\prime},\left(\right.$ H) $5^{\prime}$. 